\author{
JANINA PACH \\ Uniwersytet Pedagogiczny w Krakowie, Polska \\ Pedagogical University of Cracow, Poland
}

\title{
Formy i skutki niepłacenia oraz wyłudzania zwrołu podatku w Polsce na wybranych przykładach
}

\section{Forms and Effects of Non-Payment and Tax Frauds in Poland Based on Selected Examples}

Streszczenie: Podatki stanowią ważne źródło dochodów budżetu państwa, finansujących wydatki publiczne. Jednakże nie wszyscy podatnicy z różnych względów (ekonomicznych, politycznych czy religijnych) uczciwie je płacą. Cierpi na tym nie tylko budżet, ale również ci podatnicy, którzy nie uchylają się od obowiązku podatkowego i systematycznie płacą podatki. Gdyby bowiem nie istniało w różnych formach zjawisko niepłacenia podatków oraz wyłudzania ich zwrotu, to potencjalne opodatkowanie społeczeństwa mogłoby być niższe. Przedmiotem artykułu jest przybliżenie istoty podatków, ich funkcji i znaczenia, pokazanie głównych sposobów i form niepłacenia podatków, jak również unikania opodatkowania, $\mathrm{w}$ tym oszustw podatkowych. Głównym celem badawczym jest próba odpowiedzi na następujące pytania: Jaka jest skala niepłacenia przez podatników podatków w Polsce? Na czym polega zjawisko wyłudzania zwrotu podatku? Dlaczego zjawisko unikania opodatkowania i wyłudzania zwrotu podatku w największej mierze dotyczy podatku od towarów i usług, będącego głównym źródłem dochodów budżetowych? Uzyskane odpowiedzi pozwolą nie tylko wskazać przyczyny niepłacenia podatków, w tym oszustw podatkowych, ale również kierunki przeciwdziałania tym zjawiskom.

Abstract: Taxes are an important source of income to a state budget, from which public expenditure is financed. However, not all taxpayers are willing to pay them honestly for various reasons (economic, political or religious). Not only does the budget suffer from it, but also those taxpayers who do not avoid the fiscal obligation and regularly pay their taxes. For if various forms of the phenomenon of not paying taxes or extorting tax refund did not exist, a potential taxation of society could be lower. The article aims at describing the essence of taxes, as well as their function and importance; it aims at presenting the main ways and forms of not paying taxes and tax avoidance and evasion. The main research objective is to attempt an answer to the following questions: What is the essence and the economic-social content of tax? What is the scale of tax avoidance by taxpayers in Poland? What does the phenomenon of extortion of tax refund consist in? Why does the phenomenon of tax avoidance and extortion of tax refund concern mostly tax on goods and services? The answers to these questions will allow not only to indicate the reasons for tax avoidance and evasion, but also a policy for counteracting these phenomena.

Słowa kluczowe: optymalizacja podatkowa; oszustwa podatkowe; system podatkowy; unikanie opodatkowania

Keywords: extortion of tax refund; fiscal optimization; tax avoidance; tax evasion; tax system 
Otrzymano: 6 stycznia 2018

Received: 6 January 2018

Zaakceptowano: 21 maja 2018

Accepted: 21 May 2018

\section{Sugerowana cytacja / Suggested citation:}

Pach, J. (2018). Formy i skutki niepłacenia oraz wyłudzania zwrotu podatku w Polsce na wybranych przykładach. Prace Komisji Geografii Przemysłu Polskiego Towarzystwa Geograficznego, 32(2), $175-189$. https://doi.org/10.24917/20801653.322.12

\section{WSTĘP}

Podatki to rodzaj daniny publicznej, która na przestrzeni wieków podlegała głębokiej ewolucji. W świetle ustawy z dnia 29 sierpnia 1997 roku o ordynacji podatkowej podatek to „publicznoprawne, nieodpłatne, przymusowe oraz bezzwrotne świadczenie pieniężne na rzecz Skarbu Państwa, województwa, powiatu lub gminy, wynikające z ustawy podatkowej". Klamrą spinającą wymienione cechy podatku jest przymusowy charakter tego świadczenia, bowiem państwo nakłada podatki jednostronnie i ma przywilej stanowienia prawa określającego podatki, ich wymiar, pobór, egzekucję i środki represyjne. Ma więc możliwość jego przymusowego wyegzekwowania w sytuacji, w której podmiot uchyla się od jego uiszczenia lub dokonuje oszustw podatkowych. Przymusowość odróżnia podatek od pozostałych świadczeń na rzecz państwa i jest zabezpieczona sankcjami karnymi oraz podatkowymi. Ma ona zabezpieczyć realizację funkcji państwa, finansowanych przez odpowiednie dochody budżetowe państwa i jednostek samorządu terytorialnego.

Przedmiotem artykułu jest przybliżenie istoty podatków, ich cech i funkcji (w tym przede wszystkim fiskalnej), a także zaprezentowanie głównych mechanizmów i form niepłacenia podatków w Polsce, unikania i uchylania się podmiotów od opodatkowania, $\mathrm{w}$ tym różnorodnych oszustw podatkowych, oraz ekonomiczno-społecznych skutków z nich wynikających.

Sformułowana hipoteza badawcza brzmi: „Unikanie opodatkowania oraz oszustwa podatkowe stanowią główne źródło luki podatkowej w Polsce".

Głównym celem badawczym jest próba odpowiedzi na następujące pytania:

- jaka jest istota, cechy i treść ekonomiczno-społeczna podatków?

- jakie są przyczyny i formy niepłacenia podatków w Polsce?

- czym różni się zjawisko unikania podatków od oszustw podatkowych?

- na czym polega mechanizm wyłudzania zwrotu podatku i jakie formy przyjmuje w Polsce?

- jaka jest skala unikania opodatkowania i oszustw podatkowych w Polsce w świetle statystyk?

Odpowiedzi na powyższe pytania pozwolą na weryfikację hipotezy badawczej i ponadto pozwolą ocenić podejmowane próby uszczelniania systemu podatkowego w Polsce.

\section{PODATKI JAKO SZCZEGÓLNA DANINA PUBLICZNA}

Obowiązek uiszczania danin publicznych pojawił się wraz z procesem kształtowania się życia społecznego oraz tworzenia się różnorodnych form organizacyjnych państwa. 
Wynikał on z konieczności finansowania funkcji państwa, takich jak zapewnienie bezpieczeństwa, ładu, porządku, sądownictwa, administracji itd. Z czasem funkcje te podlegały licznym poszerzeniom, uwzględniającym różne aspekty życia społeczno-gospodarczego. Na początku daniny publiczne ponosiły określone grupy społeczne, tj. mieszczaństwo czy rolnicy (szlachta i duchowieństwo były z tego obowiązku zwolnione), jednak z upływem czasu to się zmieniło. W procesie historycznym wyodrębniły się trzy zasadnicze formy danin publicznych: osobiste (np. praca na rzecz państwa, służba wojskowa), rzeczowe (żywność) oraz pieniężne. Pomimo iż daniny pieniężne pojawiły się najpóźniej, to ze względu na swoją użyteczność stały się najbardziej powszechne i z czasem wyparły daniny rzeczowe i osobiste.

Współcześnie daniny publiczne mają zróżnicowany charakter i obejmują: podatki, opłaty, cła, niepodatkowe należności budżetowe, przymusowe pożyczki na cele publiczne, składki obowiązkowe (Krzywoń, 2011). Jednakże największe znaczenie ze względów fiskalnych i gospodarczych mają podatki.

W literaturze przedmiotu i w aktach prawnych funkcjonuje wiele węższych i szerszych definicji podatków. Cytowano już we wstępie definicję podatku w ordynacji podatkowej. Podobnie podatek definiuje ustawa o finansach publicznych - jako daninę publiczną, którą wyróżniają następujące cechy konstytutywne:

- pieniężny charakter - w przeciwieństwie do wcześniej stosowanych naturalnych (rzeczowych) form danin publicznych, co wpływa na konstrukcję podatku, jego wymiar i pobór;

- przymusowość - oznacza możliwość zastosowania sankcji wobec osób prawnych i fizycznych, będących w obowiązku podatkowym, a uchylających się od jego płacenia;

- ogólność (powszechność) - oznacza powinność jego zapłaty przez podmioty będące w obowiązku podatkowym;

- bezzwrotność - polega na definitywnym pobraniu przez podmiot publiczny podatku należnego;

- nieodpłatność (nieekwiwalentność) - wynika z braku bezpośredniego świadczenia ze strony państwa czy samorządu na rzecz podatnika.

Szczególny charakter podatku jako daniny publicznej wynika z powyższych cech oraz z funkcji, jakie pełni. Podatki są nie tylko źródłem dochodów budżetu (pełniąc funkcję fiskalną), ale również ważnym narzędziem polityki gospodarczej i społecznej. Wynika to z faktu, iż podatki pełnią także funkcję redystrybucyjną w zakresie PKB, funkcję stymulującą procesy gospodarcze i funkcję informacyjną o ich przebiegu (Pach, 2017).

\section{PojęCIE I STRUKTURA SYSTEMU PODATKOWEgo W POlsce}

Funkcjonujący obecnie system podatkowy w Polsce ukształtował się pod wpływem szeregu różnorodnych czynników o charakterze wewnętrznym i zewnętrznym. Do najważniejszych z nich zaliczyć należy (Pach, 2017):

- powojenny system polityczny oraz centralizm gospodarczy,

- realizowaną po 1989 roku transformację społeczno-ustrojową i gospodarczą powiązaną z reformami rynkowymi,

- reformy samorządowe rozpoczęte w 1990 roku, wiążące się z wydzieleniem podatków i opłat lokalnych stanowiących dochody budżetów gmin, 
- reformę podatków dochodowych obejmującą: wprowadzenie 1 stycznia 1992 roku podatku dochodowego od osób fizycznych (PIT) oraz, nieco później, podatku dochodowego od osób prawnych (CIT),

- wprowadzenie 5 lipca 1993 roku podatku od towarów i usług (VAT), który zastąpił dotychczasowy podatek obrotowy,

- dostosowanie polskiego prawa podatkowego do wymogów unijnych, rozpoczęte po podpisaniu układu o stowarzyszeniu się Polski ze Wspólnotami Europejskimi a usankcjonowane układem akcesyjnym,

- proces koordynacji i harmonizacji podatków konsumpcyjnych (VAT i akcyza) z systemem podatkowym Unii Europejskiej,

- uchwalenie ordynacji podatkowej (1 stycznia 1998 roku) oraz ustawy o finansach publicznych z dnia 27 sierpnia 2009 roku,

- uchwalenie ustawy z dnia 16 listopada 2016 roku o Krajowej Administracji Skarbowej.

W wąskim znaczeniu system podatkowy oznacza zbiór zintegrowanych i wewnętrznie spójnych podatków obowiązujących w danym kraju (Ofiarski, 2013). W tym rozumieniu systemu można wyróżnić trzy zasadnicze rodzaje systemów podatkowych:

1. systemy o znacznej przewadze podatków przychodowych,

2. systemy o znacznej przewadze podatków dochodowych,

3. systemy o przewadze podatków konsumpcyjnych.

Podział ten nawiązuje do trwającej dyskusji dotyczącej tego, której fazy dochodu narodowego w większym stopniu dotyczyć powinno opodatkowanie: czy fazy jego tworzenia (systemy podatkowe o przewadze podatków przychodowych i dochodowych), czy fazy podziału dochodu (systemy o przewadze podatków konsumpcyjnych). To z kolei wymaga zastanowienia się nad tym, co w większej mierze decyduje o zdolności podatkowej: czy przychód i dochód, czy wielkość i kierunki ich przeznaczenia na konsumpcję bądź majątek. Są to zagadnienia ważne, gdyż nadmierne opodatkowanie przychodów i dochodów może skutkować ucieczką podmiotów do szarej strefy i rajów podatkowych, z kolei nadmierne opodatkowanie konsumpcji może skutkować innymi formami uchylania się od opodatkowania. Na polski system podatkowy aktualnie składa się 13 podatków, z których cztery określa się mianem podstawowych, a dziewięć uzupełniających (Wolański, 2009; Pach, 2017: 230-243).

Tab. 1. Podatki obowiązujące w Polsce

\begin{tabular}{|l|l|}
\hline \multicolumn{1}{|c|}{ PODATKI PODSTAWOWE } & \multicolumn{1}{|c|}{ PODATKI UZUPEŁNIAJĄCE } \\
\hline $\begin{array}{l}\text { podatek dochodowy od osób prawnych (CIT) } \\
\text { podatek dochodowy od osób fizycznych (PIT) } \\
\text { podatek od towarów i usług (VAT) } \\
\text { podatek akcyzowy }\end{array}$ & $\begin{array}{l}\text { podatek od spadków i darowizn } \\
\text { podatek od nieruchomości } \\
\text { podatek rolny } \\
\text { podatek leśny } \\
\text { podatek od gier } \\
\text { podatek od środków transportowych } \\
\text { podatek od czynności cywilnoprawnych } \\
\text { podatek tonażowy } \\
\text { podatek od wydobycia niektórych kopalin }\end{array}$ \\
\hline
\end{tabular}

Źródło: opracowanie własne na podstawie Wolański (2009) 
Podatki podstawowe to te, które dotykają najszerszej grupy podatników, w tym przedsiębiorców, dostarczają największych dochodów do budżetu i najsilniej oddziałują na decyzje przedsiębiorców. Natomiast podatki uzupełniające mają funkcję uszczelniającą system podatkowy i dotyczą różnych sytuacji i zdarzeń podatkowych nieuwzględnionych w grupie podstawowych podatków, np. posiadania nieruchomości.

Wymienione podatki z punktu widzenia sposobu płacenia i techniki poboru podatku w Polsce można podzielić na bezpośrednie i pośrednie. Do pierwszej grupy należy zaliczyć te opłacane przez podmioty bezpośrednio zobowiązane do zapłacenia podatku, na które ustawodawca nałożył obowiązek podatkowy, np. podatek dochodowy od osób fizycznych oraz podatek dochodowy od osób prawnych. Natomiast do podatków pośrednich należą te, których konstrukcja rozdziela podmiot gospodarczy zobowiązany do ich naliczania i płacenia od podmiotu, który ponosi faktyczny ciężar ekonomiczny, np. podatek od towarów i usług, podatek akcyzowy.

Każda z tych konstrukcji i technik poboru podatku stwarza inne potencjalne możliwości do niepłacenia, unikania lub wyłudzania zwrotu podatku, o czym będzie mowa w dalszej części artykułu. W związku z tym niezmiernie ważne są aparat skarbowy oraz precyzyjne prawo podatkowe, które w szerokim znaczeniu, oprócz zbioru zintegrowanych prawnie i ekonomicznie podatków, stanowią filary systemu podatkowego w Polsce.

Aparat skarbowy wiąże wszystkie elementy systemu podatkowego. Jego zadaniem jest organizacja wymiaru, poboru, kontroli i egzekucji podatków. Struktura aparatu skarbowego przeszła wiele zmian na przestrzeni lat - na przełomie lat osiemdziesiątych i dziewięćdziesiątych oraz ostatnio - które przełożyły się na funkcjonowanie administracji skarbowej ${ }^{1}$. Od lutego 2017 roku funkcjonuje Skonsolidowana Krajowa Administracja Skarbowa składająca się z 16 izb administracji skarbowej, 400 urzędów skarbowych oraz 16 urzędów celno-skarbowych (por. ryc. 1).

Skonsolidowana Krajowa Administracja Skarbowa podporządkowana jest ministrowi finansów publicznych. Z kolei dyrektor Izby Administracji Skarbowej nadzoruje wykonywanie zadań przez naczelników urzędów skarbowych oraz naczelnika urzędu celno-skarbowego. Natomiast naczelnicy urzędów skarbowych odrębnie funkcjonujących do 28 lutego 2017 roku mają kompetencje naczelników urzędów skarbowych oraz naczelników urzędów celnych w zakresie poboru podatków, należności celnych, nieopodatkowanych należności budżetowych oraz opłat (Struktura Krajowej Administracji Skarbowej, 2017).

Źródłem obowiązującego prawa regulującego podatki są: konstytucja RP, ordynacja podatkowa, ustawy podatkowe, ratyfikowane umowy międzynarodowe, rozporządzenia, akty prawa miejscowego. Zgodnie z nimi podstawą prawną do nakładania podatków w Polsce jest obowiązująca od 17 października 1997 roku konstytucja Rzeczypospolitej Polskiej z dnia 2 kwietnia 1997 roku, której art. 217 stanowi: „Nakładanie podatków i innych danin publicznych oraz określanie podmiotów opodatkowania, przedmiotów opodatkowania, stawek podatkowych, kategorii podmiotów zwolnionych od podatków i zasad przyznawania ulg oraz umorzeń podatkowych może następować wyłącznie w drodze ustawy".

${ }^{1}$ Na strukturę sprzed reformy z 28 lutego 2017 roku składały się trzy niezależne od siebie piony: administracja podatkowa (16 izb skarbowych oraz 400 urzędów skarbowych), Służba Celna (16 izb celnych), 45 urzędów celnych wraz ze 143 oddziałami celnymi, kontrola skarbowa (16 urzędów kontroli skarbowej, osiem zamiejscowych ośrodków urzędów kontroli skarbowej). Specjaliści uważają, że powodowało to rozproszenie i powielanie niektórych zadań, związanych z poborem podatków i ceł, i obniżało efektywność całego systemu podatkowego. 
Ryc. 1. Skonsolidowana Krajowa Administracja Skarbowa

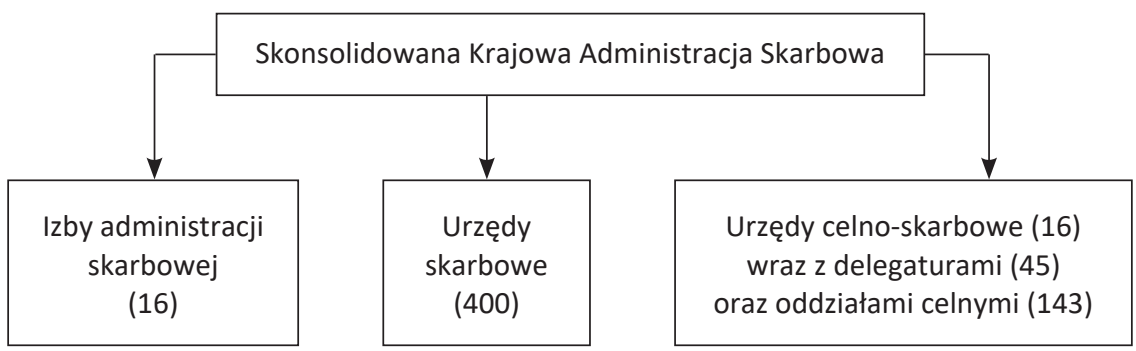

Źródło: opracowanie własne na podstawie Struktura Krajowej Administracji Skarbowej (2017)

Jakimi cechami winien charakteryzować się system podatkowy kraju? Większość nich nawiązuje do zasad podatkowych sformułowanych przez A. Smitha i A. Wagnera (Owsiak, 2005: 189), podkreślających:

- wydajność, zapewniającą nagromadzenie odpowiednich dochodów publicznych $\mathrm{w}$ wysokości pozwalającej pokryć uznane za niezbędne wydatki publiczne,

- elastyczność, polegającą na łatwym dostosowaniu podatków do zmieniających się wydatków publicznych oraz koniunktury gospodarczej,

- taniość, charakteryzującą się niskim udziałem kosztów poboru w sumie wymierzonych podatków, co wpływa na wydajność systemu podatkowego (Rosiński, 2010),

- trudność w omijaniu i niepłaceniu podatków i w stosowaniu oszustw podatkowych,

- techniczną łatwość dla podatników, nawiązującą do zasad w rozliczaniu podatków, chodzi o nieskomplikowaną technikę podatkową,

- sprawiedliwość i dogodność rozwiązań podatkowych.

Cechy te wiążą się z postulatem racjonalnego systemu podatkowego, który winien charakteryzować się przede wszystkim (Gomułowicz, Małecki, 2013):

1. efektywnością oraz sprawnością,

2. neutralnością podatkową,

3. efektywnością koniunkturalną,

4. taniością wymiaru i poboru podatków,

5. wewnętrzną zwartością podatków,

6. ochroną źródeł opodatkowania,

7. łagodnym ciężarem podatkowym (Bessard, 2009).

Wydaje się, iż wiele z tych zasad pozostaje $\mathrm{w}$ sprzeczności, co może powodować trudności w stworzeniu racjonalnego systemu podatkowego.

\section{GŁÓWNE METODY I FORMY NIEPŁACENIA I UNIKANIA OPODATKOWANIA}

Polski system podatkowy cechuje wiele niekorzystnych zjawisk, takich jak:

- unikanie opodatkowania,

- stosowanie optymalizacji podatkowej,

- ucieczka podatników do rajów podatkowych,

- szeroko rozumiana przestępczość podatkowa, w tym: oszustwa podatkowe, wyłudzanie zwrotu podatków, rozrost szarej i czarnej strefy oraz szereg innych. 
Duży wpływ na te zjawiska ma ukształtowana w Polsce moralność podatkowa, określana jako „zbiór norm moralnych przyjętych w danym środowisku, dotyczący postawy podatnika względem wnoszenia i uiszczania obowiązkowych opłat do budżetu państwa" (Szulc, 2013).

Na moralność podatkową przedsiębiorstw i osób fizycznych wpływa przede wszystkim: budowa systemu podatkowego, jakość administracji podatkowej, efektywność aparatu wymiaru i kontroli podatków, prawo podatkowe, poziom rozwoju społeczno-gospodarczego, system polityczny państwa oraz szereg innych czynników. Sytuują się one nie tylko po stronie podatnika, ale i po stronie państwa i samorządu terytorialnego, będących dysponentami dochodów podatkowych. Moralność podatkowa kształtuje się w społeczeństwach przez długie lata i determinuje skalę niepłacenia podatków oraz uchylania się podmiotów od opodatkowania. Przyczyny niepłacenia podatków generalnie są różne:

- polityczne: brak zgody podatnika na realizowaną przez władze politykę, finansowanie określonych programów politycznych, partii politycznych itp.,

- religijne: przykładowo zbyt duże zaangażowanie państwa w religię bądź jego brak, finansowanie instytucji religijnych niezgodnych z przekonaniami religijnymi podmiotów,

- ekonomiczne: chęć zatrzymania większego dochodu wynikająca z kalkulacji podatnika, dotyczącej korzyści z przywłaszczenia podatkowego w porównaniu z ryzykiem z niego płynącym. Im wyższa jest skala podatkowa, tym silniejsza jest pokusa niepłacenia i ucieczki przed podatkiem (Bernal, 2008).

Podatnik wykorzystuje różne sposoby zatrzymania potencjalnego podatku, dokonując zatajeń podatkowych, niewłaściwej kwalifikacji kosztów itp. Niepłacenie podatków może zatem przyjąć różne formy: unikania opodatkowania i różnych oszustw podatkowych. Unikanie opodatkowania jest najłagodniejszym sposobem niepłacenia podatku. Ma ono na celu zmniejszenie ciężaru opodatkowania i może nastąpić w sposób legalny, przy wykorzystaniu elementów konstrukcyjnych danego podatku, czyli ulgi, zwolnienia podatkowego oraz odliczenia lub niewchodzenia w obowiązek podatkowy, np. nieprzyjęcie spadku, rezygnacja z wynajmu mieszkania. Szczególnym przykładem unikania opodatkowania jest optymalizacja podatkowa, sama w sobie dozwolona i legalna, a często błędnie traktowana jako oszustwo podatkowe (Wyciślok, 2013). Celem optymalizacji jest zminimalizowanie obciążenia podatkowego w przedsiębiorstwie poprzez: odpis od podstawy opodatkowania usług doradczych (świadczonych często poza granicą kraju), usług z zakresu badania rynku, usług reklamowych, usług świadczonych zdalnie. Stanowią one koszty pomniejszające przychody, co w efekcie zmniejsza podstawę opodatkowania (por. ryc. 2).

Wykres wskazuje, że o ile dywidendy w ostatnich latach utrzymywały się na zbliżonym poziomie (przy lekkiej tendencji spadkowej), to płatności za usługi doradcze i zarządcze mocno wzrosły. W odróżnieniu od dywidend, tego rodzaju płatności stają się kosztem dla spółki i pomniejszają zysk do opodatkowania w Polsce. Według Ministerstwa Finansów może to świadczyć o tym, że usługi doradcze i zarządcze były wykorzystywane do optymalizacji podatkowej lub transferu dochodów do ich udziałowców.

Innym sposobem unikania podatków we własnym kraju jest przeniesienie działalności do tzw. rajów podatkowych. W polskim prawie podatkowym nie ma definicji raju podatkowego, stosuje się pojęcie „państwa i terytoria stosujące szkodliwą konkurencję podatkową w zakresie podatku dochodowego od osób prawnych (rozporządzenie 
Ryc. 2. Płatności polskich podmiotów za usługi doradcze w krajach UE w latach 2011-2015

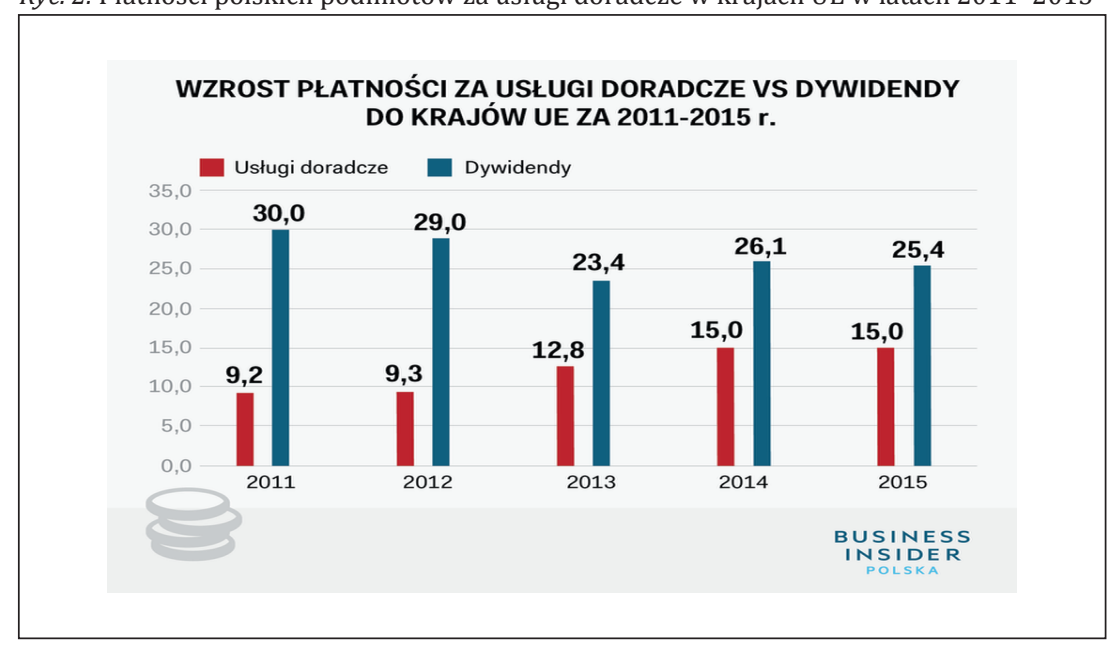

Źródło: Skarbówka zwęszyła nowy wyciek podatków (2017)

Ministra Rozwoju i Finansów z dnia 17 maja 2017 r. w sprawie określenia krajów i terytoriów stosujących szkodliwą konkurencję podatkową w zakresie podatku dochodowego od osób prawnych).

W literaturze przedmiotu występują bliskoznaczne określenia, takie jak: „oazy podatkowe”, „azyle podatkowe” lub „terytoria-offshore” stosowane często zamiennie. Do podstawowych cech rajów podatkowych można zaliczyć (Mazur, 2012: 99):

a) brak podatków bądź bardzo niskie ich stawki,

b) stabilne i korzystne regulacje prawne dla przedsiębiorców,

c) przestrzeganie tajemnicy bankowej,

d) łatwość założenia firmy oraz niskie koszty jej prowadzenia,

e) stabilny system polityczno-ekonomiczny,

f) brak efektywnej wymiany informacji podatkowych z innymi państwami.

Raje podatkowe różnią się atrakcyjnością lokalizacji i oferowanymi warunkami. Stosując kryterium warunków, można je klasyfikować następująco (Zyniewicz, Załupka, 1999: 28):

a) grupa krajów, w których osoby fizyczne mogą liczyć na łagodne traktowanie prawne, czyli Monako, Wyspy Bahama, Bermudy i Kajmany,

b) kraje, w których majątek i dochód nie jest opodatkowany: Vanatu i Kajmany,

c) kraje, w których opodatkowane są dochody uzyskane tylko na ich terytorium, natomiast zwolnieniom z podatku podlegają przychody pozyskane z zagranicy: Filipiny, Panama, Kostaryka, Haiti, Liberia,

d) obszary o preferencyjnych stawkach podatkowych w wybranych przedsięwzięciach gospodarczych, m.in.: Anguilla, Jamajka.

Raje podatkowe to nie tylko egzotyczne wyspy leżące w odległej Oceanii czy na Morzu Karaibskim. Nie brakuje ich także w Europie. Do tej kategorii polski fiskus zalicza: Monako, Andorę, Liechtenstein oraz Sark (wyspa u wybrzeży francuskiej Normandii). W ramach polityki ujawniania rajów podatkowych Unia Europejska umieściła na czarnej liście 17 krajów i terytoriów, natomiast Korea Południowa, Barbados, Saint Lucia, Bahrajn, Panama i Zjednoczone Emiraty Arabskie zostały wymienione jako 
„niewspółpracujące z wymiarem sprawiedliwości w celach podatkowych”. Malediwy, Bahrajn, Hongkong, Monako to niektóre z 31 państw i terytoriów, które według polskich organów podatkowych prowadzą szkodliwą konkurencję podatkową. Oznacza to, że promują nieuczciwe praktyki podatkowe lub nie dzielą się ważnymi informacjami finansowymi z Unią Europejską ${ }^{2}$.

W świetle danych raportu Komisji Europejskiej budżet Polski jest szczuplejszy nawet o 46 mld zł rocznie z tytułu niepłacenia podatku dochodowego od osób prawnych (CIT), zatrzymanego przez korporacje wykorzystujące raje podatkowe. Dla porównania koszty utrzymania całej armii w 2015 roku wyniosły 38 mld zł (Polska traci miliardy..., 2018). Niepłacenie podatków przez międzynarodowe korporacje to nie tylko dziura w budżecie, ale cios w polskie firmy, bo korporacje mające do dyspozycji dodatkowe pieniądze mogą destabilizować rynek, finansować nieuczciwą konkurencję.

W związku z aferą Luxembourg Leaks ujawniono, że ponad 340 międzynarodowych firm z UE latami korzystało z dogodnych umów z luksemburskim fiskusem redukującym im podatek CIT. Przez takie procedery pozostałe kraje UE traciły wpływy podatkowe szacowane na równowartość nawet $500 \mathrm{mld}$ zł.

\section{CO TO JEST OSZUSTWO PODATKOWE?}

Unikanie opodatkowania, jego różne formy scharakteryzowane powyżej, w myśl prawa podatkowego nie są oszustwem podatkowym. Oszustwo podatkowe wiąże się z naruszeniem norm podatkowych, nakładających obowiązek zgłoszenia organowi podatkowemu przedmiotu i podstawy opodatkowania. Natomiast uchylanie się od opodatkowania jest prawnokarne i decyduje o bycie oszustwa podatkowego - w myśl art. 54 Kodeksu karnego skarbowego. Artykuł ten stwierdza, że podatnik, który uchylając się od opodatkowania, nie ujawnia właściwemu organowi przedmiotu lub podstawy opodatkowania lub nie składa deklaracji, przez co naraża podatek na uszczuplenie, podlega stosownej karze. Z kolei art. 56 Kodeksu karnego skarbowego dotyczy podania nieprawdy lub zatajania prawdy w deklaracji bądź niedopełnienia obowiązku zawiadomienia o zmianie objętych nimi danych w celu narażenia podatku na uszczuplenie, kar w postaci grzywny lub pozbawienia wolności, albo obu kar łącznie. P. Kardas i G. Łabuda oszustwami podatkowymi określają delikty, o których mowa tylko w art. 76 Kodeksu karnego skarbowego, ponieważ posiadają one elementy wprowadzania w błąd lub wykorzystania błędu, mają zatem znamiona charakterystyczne dla oszustwa (Kardas, Łabuda, 2003).

Według T. Grzegorczyka oszustwo podatkowe związane jest z całkowitym lub częściowym uchyleniem się od podatku. Obejmuje przede wszystkim takie zachowania podatnika, jak:

- niezgłoszenie przedmiotu opodatkowania,

- niezłożenie w terminie deklaracji,

- nieodpowiednia kwalifikacja, np. kosztów uzyskania dochodu,

- lokalizacja działalności w szarej strefie,

- firmanctwo - jako oszustwo skarbowe polega na posługiwaniu się cudzym nazwiskiem lub nazwą do prowadzenia działalności, którą w rzeczywistości prowadzi inna osoba,

- wyłudzenia zwrotu podatku.

${ }^{2} \mathrm{Na}$ listę szkodliwych rajów podatkowych OECD (i polską zarazem) trafiają te kraje i terytoria, które nie współpracują z obcymi organami podatkowymi w zakresie wymiany informacji fiskalnej. 
Oszustwa podatkowe przybierają różną postać w zależności od rodzaju i charakteru podatku. Na inne oszustwa narażone są podatki dochodowe o charakterze bezpośrednim, na inne podatki majątkowe, a jeszcze na inne podatki konsumpcyjne o charakterze pośrednim, np. podatek od towarów i usług, podatek akcyzowy. Przykładem częściowego uchylania się od podatku dochodowego od osób fizycznych (PIT) jest: niewykazanie wszystkich źródeł przychodów (np. zrealizowanych za granicą), wadliwa prawnie kwalifikacja kosztów uzyskania przychodów. Podobnie wygląda sytuacja w przypadku podatku dochodowego od osób prawnych (CIT). Częściowe uchylanie się od podatku ma miejsce, gdy przedsiębiorca w koszty uzyskania przychodu wlicza elementy wydatków, które w myśl ustawy nimi nie są, korzysta z ulg i zwolnień podatkowych prawnie mu nienależnych (nagina sytuację do możliwości prawnych), celowo doprowadza firmę do upadłości, by zmniejszyć podatek.

Przykładem całkowitego uchylania się od opodatkowania jest funkcjonowanie podmiotów (osób fizycznych i prawnych) w szarej strefie, niepłacących podatków od osiągniętych dochodów. Przyczyn tego zjawiska jest wiele, w tym wysokie obciążenie pracy różnymi kosztami, np. podatkami lub składkami ubezpieczeniowymi, oraz zbyt niski poziom kwoty wolnej od podatku, uniemożliwiający odpis całkowitych kosztów, co szczególnie dotyczy pracowników o niskich kwalifikacjach i zarobkach (Barszcz, 2010: 2). Funkcjonując w szarej strefie, zarówno pracownik, jak i firma nie płacą podatków, umniejszając w ten sposób wpływy do budżetu.

Według szacunków ekspertów firmy doradczej PwC szara strefa w Polsce stanowi prawie 12,5\% produktu krajowego brutto, co oscyluje wokół 390 mld zł (Szara strefa w Polsce..., 2017). Jednakże szacunki dotyczące wartości szarej strefy w Polsce różnią się w zależności od przyjętej metodologii. Niektóre z nich mówią nawet o wielkości 25\% PKB. Dane te wskazują, iż jest to poważny problem. Potencjalne dochody podatkowe z szarej strefy, szacowane na ponad $50 \mathrm{mld}$ zł, mogłyby w pełni pokryć deficyt budżetowy z 2016 roku, a to obniżyłoby zadłużenie publiczne Polski.

Szara strefa ma różne oblicza, od tego najłagodniejszego, przejawiającego się w przysłowiowej sprzedaży malin przez rolnika na placu, poprzez wyżej omówione, aż do najgroźniejszego, określanego mianem czarnej strefy. W niej działają mafie gospodarcze, które w sposób profesjonalny zajmują się przemytem, wyłudzeniami VAT czy akcyzy. Są to sprofesjonalizowane środowiska, będące w stanie generować ogromne straty dla skarbu państwa i zyski dla siebie, na poziomie 7-10 mld zł rocznie w przypadku mafii paliwowej. Takich mafii, o dużym zasięgu, mamy w Polsce przynajmniej 18, w różnych branżach. Szacuje się, iż ok. 10\% paliw pochodzi z nielegalnego importu. Podobne zjawisko można zaobserwować na rynku tytoniu, gdzie co czwarty papieros jest produkowany nielegalnie na terytorium naszego kraju lub jest do Polski przemycany. W przypadku papierosów to jest rocznie ok. 6,5 mld zł strat, które są zyskiem dla mafii tytoniowej. Straty wynikające z niedoborów w opłacaniu samej akcyzy na wyroby tytoniowe szacowane były na blisko 5 mld zł (Ile Polska traci na szarej strefie, 2018).

W Polsce i w innych krajach UE zjawiskiem szczególnie niebezpiecznym są wyłudzenia podatku od towarów i usług, dokonywane w sposób świadomy i zorganizowany przez grupy przestępcze. Najczęstszymi formami wyłudzeń podatkowych VAT jest:

- fikcyjny wywóz towaru, który w rzeczywistości nie opuścił kraju, a deklarowany jest jako eksport (Górczak, 2017),

- fikcyjne miejsce świadczenia usług, które w rzeczywistości są świadczone na terenie kraju, a fikcyjnie deklarowane są jako wykonane poza jego terytorium, 
- czynność pozorna, deklarowana jako eksport, gdzie wywóz faktycznie miał miejsce, lecz wywiezione towary nie miały wartości.

Czynnikiem ułatwiającym powyższe wyłudzenia jest obowiązująca na obszarze Unii Europejskiej stawka 0\% dla towarów i usług będących przedmiotem eksportu.

Niemal plagą w wyłudzeniach podatku VAT jest stosowany mechanizm karuzeli podatkowej. Karuzela podatkowa to jeden ze sposobów wyłudzania zwrotu podatku od towarów i usług przez podmiot, który jest do tego nieuprawniony, poprzez wykonywanie transakcji faktycznych i pozornych, w których w ramach zaplanowanych przez oszustów ról uczestniczy wiele podmiotów gospodarczych: dostawca, znikający podmiot, bufor, broker. Mechanizm karuzeli podatkowej opiera się na znikającym podmiocie, który w praktyce nie prowadzi działalności gospodarczej, ale wystawia faktury, które w rzeczywistości nie dokumentują zdarzeń gospodarczych. Podmiot ten znika bez śladu, pozostawiając po sobie nieuregulowane kwoty podatku. Natomiast towar przechodzi przez kolejne łańcuchy transakcji, do tzw. bufora, nadającego wiarygodność fakturowanym transakcjom (są to najczęściej podmioty znane, o odpowiedniej historii działalności). Natomiast broker, ostatni z podmiotów, odpowiada za sprzedaż towaru poza granicami kraju w ramach wewnątrzwspólnotowej dostawy towarów i występuje do urzędu skarbowego o zwrot podatku VAT. Informacje o oszustwach opartych na karuzeli podatkowej trafiają do opinii publicznej. Poniżej tylko dwie przykładowe sprawy.

Mazowiecki Urząd Celno-Skarbowy wykrył karuzelę podatkową, w której uczestniczyło 170 podmiotów polskich i 55 zagranicznych - poinformowało w komunikacie Ministerstwo Finansów. Wartość wyłudzonego podatku VAT to ponad $108 \mathrm{mln}$ zł ( $W y$ łudzenia VAT, 2017; Wykryto karuzelę podatkowq..., 2017).

Blisko 82 mld zł wyniosła w 2015 roku łączna suma kwot wskazanych w fikcyjnych fakturach, ujawnionych przez Urząd Kontroli Skarbowej - poinformowali sejmową komisję finansów publicznych prokuratorzy zajmujący się przestępczością gospodarczą (82 mld zł na fikcyjnych fakturach VAT..., 2017).

W wyniku oszustw nakierowanych na zaniżenie należnego podatku i wyłudzania podatku powstaje luka podatkowa, rozumiana jako wysokość zobowiązań podatkowych podatnika, które zostały przez niego nieuregulowane na czas (Pauch, 2015: 637). W latach 2006-2015 nastąpił jej wzrost z 0,6\% PKB w 2006 roku do 2,4\% PKB 2013 roku (por. ryc. 3).

Największy wzrost uszczupleń podatkowych VAT nastąpił w latach 2007-2012 w związku z karuzelowymi oszustwami podatkowymi. Skarb państwa w tym okresie został narażony na straty 699 mln zł (Prokuratura Generalna, 2013: 480). Luka podatkowa VAT w Polsce jest wyższa od średniej Unii Europejskiej. Wyższą lukę w podatku VAT od Polski ma Rumunia i Słowacja, zaś najniższą lukę mają Czechy i Węgry (PwC Polska, 2017).

Luka w zakresie podatku VAT istotnie wpłynęła na wielkość ogólnej luki podatkowej, która miała miejsce w ostatnich latach w Polsce. Obrazuje ona utraconą, potencjalną kwotę podatków, która winna zasilić budżet państwa. Do głównych przyczyn luki podatkowej w Polsce należą: oszustwa podatkowe, szara sfera, nieuczciwa optymalizacja podatkowa, błędy w samowymiarze podatku, upadłość podatników (zarówno obiektywna, jak i strategiczna).

W świetle danych każdego roku z budżetu Polski wypływa ok. 46 mld zł z tytułu niezapłaconego podatku CIT oraz 45 mld z tytułu luki VAT-owskiej oraz kilka miliardów z pozostałych powodów. W świetle wyników badań Centrum Analiz i Studiów 
Ryc. 3. Luka podatkowa w Polsce w latach 2006-2015

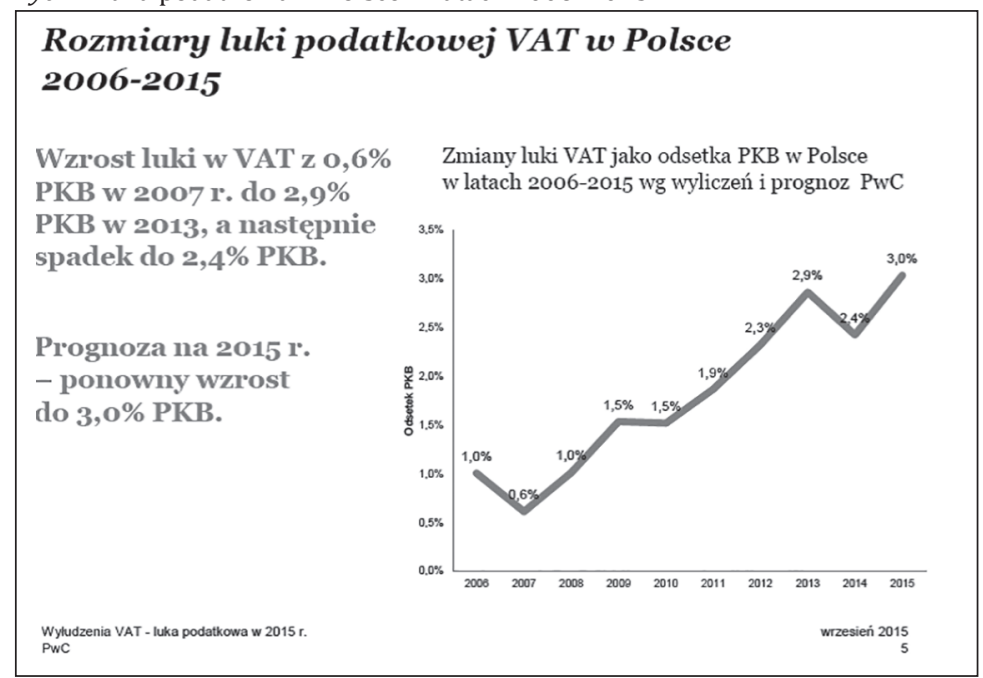

Źródło: PwC Polska (2017)

Podatkowych Szkoły Głównej Handlowej, luka na poziomie blisko 100 mld zł rocznie może zachwiać stabilnością systemu finansowego państwa (Kalus, 2017). Inną konsekwencją niepłacenia podatków oraz szeroko rozumianych oszustw podatkowych są nieprawidłowości strukturalne w gospodarce, polegające na tym, iż firmy i branże gospodarcze unikające opodatkowania mogą spowodować nieuczciwą konkurencję. Ponadto wyłudzenia podatkowe mają demoralizujący wpływ na innych podatników VAT, powodują też poczucie niesprawiedliwości wśród uczciwych podatników.

W 2016 roku rozpoczęto $\mathrm{w}$ Polsce realizację programu uszczelniania systemu podatkowego, która ma ograniczyć skutki wyciekania gotówki z budżetu państwa. Wprowadzane od 1,5 roku działania mają zgodnie z planem przynieść do końca przyszłego roku zmniejszenie luki podatkowej o 22,4 mld zł, a do końca 2020 roku w sumie o ok. 33 mld zł.

Do głównych działań na rzecz przeciwdziałania omówionym nieprawidłowościom systemu podatkowego i jego uszczelnienia zaliczyć należy przede wszystkim:

- zwiększenie publicznej świadomości zjawiska oszustw podatkowych, jego gospodarczo-prawnych i społecznych konsekwencji,

- wprowadzenie 1 lipca 2016 roku jednolitego pliku kontrolnego (JPK), zawierającego dokumenty księgowe prowadzone za pomocą programów komputerowych, przekazywane na żądanie organu podatkowego,

- pakiet paliwowy, ograniczający wyłudzanie podatku VAT - po kilku miesiącach od jego wprowadzenia oficjalny rynek oleju napędowego wzrósł o ok. 30\%,

- pakiet energetyczny i transportowy ograniczający szarą strefę,

- nowe rozwiązania legislacyjne, w tym nowelizacja ustawy o podatku od towarów i usług z 1 stycznia 2017 roku,

- poszerzenie międzynarodowej współpracy organów kontroli skarbowej w zakresie przeciwdziałania oszustwom podatkowym. 
Warto podkreślić, iż rozwiązania dotyczące przeciwdziałania zjawisku niepłacenia podatków, oszustwom podatkowym, w tym różnym formom wyłudzania podatku, muszą mieć charakter systemowy i kompleksowy.

\section{PODSUMOWANIE}

Podatki stanowią najważniejsze źródło dochodów budżetu państwa spośród wszystkich danin publicznych finansujących wydatki publiczne. Jednakże nie wszyscy podatnicy - zarówno osoby fizyczne, jak i prawne - z różnych względów (ekonomicznych, politycznych czy religijnych) uczciwie je płacą. Część z nich stosuje określone metody niepłacenia podatków oraz unikania opodatkowania, w tym optymalizację podatkową, lokalizację firm w rajach podatkowych oraz wiele innych. Działania te, o ile mieszczą się w ramach prawa, nie są oszustwami podatkowymi.

Oszustwo podatkowe polega na całkowitym lub częściowym uchylaniu się podatnika od podatku, w sposób łamiący prawo podatkowe. Obejmuje ono przede wszystkim takie zachowania podatnika, jak: niezgłoszenie przedmiotu opodatkowania, nieodpowiednią kwalifikację, np. kosztów uzyskania dochodu, firmanctwo, wyłudzanie zwrotu podatku, karuzele podatkowe i inne. Forma i skala oszustw podatkowych zależy od rodzaju i charakteru podatku. Na inne oszustwa narażone są podatki dochodowe o charakterze bezpośrednim, na inne podatki majątkowe, a jeszcze na inne podatki konsumpcyjne - podatek od towarów i usług czy podatek akcyzowy. Cierpi na tym nie tylko budżet w wyniku tzw. luki podatkowej, mniejszych rzeczywistych wpływów podatkowych od potencjalnych, ale również ci podatnicy, którzy nie uchylają się od obowiązku podatkowego i systematycznie płacą podatki.

Wiele firm płacących uczciwie podatki przegrywa w konkurencji z oszustami podatkowymi, silniejszymi ekonomicznie. Ponadto oszustwa podatkowe mają demoralizujący wpływ na innych podatników, powodując poczucie niesprawiedliwości wśród uczciwych podatników. W związku z tym wydaje się, iż rozpoczęta w 2016 roku w Polsce realizacja programu uszczelniania systemu podatkowego, która ma ograniczyć różne formy niepłacenia podatków, w tym oszustw podatkowych i wyciekania gotówki z budżetu państwa, winna być realizowana konsekwentnie i kompleksowo. Nie powinna jednak stać się uciążliwością dla uczciwych podatników, np. poprzez nadmiar sprawozdań, dokumentacji, kontroli ze strony aparatu skarbowego. Chodzi o to, aby system podatkowy był coraz bardziej przyjazny, dogodny i pewny dla uczciwych podatników.

\section{Literatura \\ References}

82 mld zł na fikcyjnych fakturach VAT w 2015 r. Tyle straciło państwo (2017, 11 września). Pozyskano z www.money.pl/gospodarka/wiadomosci/artykul/fikcyjne-faktury-vat-podatek-wyludzenie-2015,37,0,2154021.htm1

Barszcz, M. (2010). Szara strefa. Raport na temat najczęstszych oszustw podatkowych. Warszawa: Business Centre Club.

Bessard, P. (2009). Tax burden and individual rights in the OECD: an international comparison. Institut Constant de Rebecque.

Bernal, A. (2008). Zjawisko uchylania się od podatków dochodowych i metody jego ograniczania. Warszawa: Difin. 
Górczak, M. (2017, 11 września). Wyłudzenia VAT. Pozyskano z https://www.zakiewicz-adwokaci.pl/prawo/wyludzenia-vat.html

Gomułowicz, A., Małecki, J. (2013). Podatki i prawo podatkowe. Wydanie 8. Lexis Nexis. Pozyskano z www.lex.pl Górczak, M. (2017, 11 września). Wyłudzenia VAT. Pozyskano z https://www. zakiewicz-adwokaci.pl/prawo/wyludzenia-vat.html

Ile Polska traci na szarej strefie (2018, 6 stycznia). Pozyskano z https://www.money.pl/gospodarka/wiadomosci/artykul/ile-polska-traci-na-szarej-strefie-cztery,41,0,1990953.html

Kalus, K. (2017, 12 października). Ministerstwo Finansów: luka podatkowa w 2015 roku była 7,1 razy większa niż w 2007 roku. Pozyskano z www. money.pl

Kardas, P., Łabuda, G. (2013). Kryminalizacja oszustwa podatkowego w prawie karnym skarbowym. Prokuratura i Prawo, 3.

Krzywoń, A.(2011). Podatki i inne daniny publiczne - podstawowe pojęcia konstytucyjne. Zeszyty Naukowe Sądu Administracyjnego, 2, 47-58.

Mazur, Ł.(2012). Optymalizacja podatkowa. Warszawa: Wolters Kluwer.

Ofiarski, Z. (2013). Ogólne prawo podatkowe. Zagadnienia materialnoprawne i proceduralne. Warszawa: LexisNexis.

Owsiak, S. (2005). Finanse publiczne. Teoria i praktyka. Warszawa: Wydawnictwo Naukowe PWN, 189.

Pach, J. (2017). Dylematy systemu podatkowego w Polsce. Prace Komisji Geografii Przemysłu Polskiego Towarzystwa Geograficznego, 31(3), 230-243.

Pauch, D. (2015). Problem oszustw podatkowych na przykładzie podatku VAT. Zeszyty Naukowe Uniwersytetu Szczecińskiego, 848.

Polska traci miliardy przez zagraniczne holdingi (2018, 6 stycznia). Pozyskano z www.newsweek. $\mathrm{pl} / \mathrm{biznes} /$ raje-podatkowe

Prokuratura Generalna (2013). Sprawozdanie Prokuratora Generalnego z rocznej działalności prokuratury w 2012 roku.

PwC Polska (2017, 5 listopada). Luka podatkowa VAT w Polsce $w 2016$ roku będzie mniejsza. Pozyskano z http://www.pwc.pl/pl/media/2016/2016-11-23-luka-vat-2016.html

Rosiński, R. (2010). Polski system podatkowy. Poszukiwanie optymalnych rozwiq̨zań. Warszawa: Difin.

Rozporządzenie Ministra Rozwoju i Finansów z dnia 17 maja 2017 r. w sprawie określenia krajów i terytoriów stosujących szkodliwą konkurencję podatkową w zakresie podatku dochodowego od osób prawnych (Dz.U. z 2017 r. poz. 997).

Skarbówka zwęszyła nowy wyciek podatków (2017, 22 listopada) Pozyskano z https://businessinsider.com.pl/twoje-pieniadze/prawo-i-podatki/uslugi-doradcze-zwiekszaja-optymalizacje-podatkowa-nie-do-konca/

Struktura Krajowej Administracji Skarbowej (2017, 28 listopada). Pozyskano z http://www.mf. gov.pl/krajowa-administracja- skarbowa/kas/struktura-organizacyjna

Szara strefa w Polsce warta nawet 390 mld zł. Rząd ruszył do walki, sq pierwsze efekty (2017, 2 grudnia). Pozyskano z https://www.polskieradio.pl/42/5725/Artykul/

Szulc, A. (2013). Przyczyny i skutki zatrudnienia nierejestrowanego w Polsce. Warszawa: CeDeWu.

Ustawa z dnia 29 sierpnia 1997 r. - Ordynacja podatkowa (Dz.U. z 2012 r. poz.749, z późn. zm.).

Ustawa z dnia 11 marca 2004 r. o podatku od towarów i usług (Dz.U. z 2004 r. poz. 535).

Ustawa z dnia 27 sierpnia 2009 r. o finansach publicznych (Dz.U. z 2013 r. poz. 885).

Ustawa z dnia 16 listopada 2016 r. o Krajowej Administracji Skarbowej (Dz.U. z 2016 r. poz. 1947).

Wolański, R. (2009). System podatkowy w Polsce. Warszawa: Wolters Kluwer.

Wyciślok, J. (2013). Optymalizacja podatkowa, legalne zmniejszenie obciq̨żeń podatkowych. Warszawa: C.H. Beck.

Wykryto karuzelę podatkowa z udziałem 170 polskich podmiotów (2017, 10 października). Pozyskano z http://podatki.gazetaprawna.pl/artykuly/1047042,wykryto-karuzele-podatkowa-z-udzialem-170-polskich-podmiotow.html

Wyłudzenia VAT - luka podatkowa w 2015 roku i prognozy na 2016 rok (2017, 10 listopada). Pozyskano z http://www.pwc.pl/pl/media/2016/2016-11-23-luka-vat-2016.html

Zyniewicz, M., Załupka, D. (1999). Luki podatkowe. Wrocław: Netnet. 
Janina Pach, doktor habilitowany nauk ekonomicznych, profesor nadzwyczajny, kierownik Katedry Ekonomii i Polityki Gospodarczej Uniwersytetu Pedagogicznego w Krakowie. Autorka licznych artykułów naukowych z dziedziny ekonomii, międzynarodowych stosunków gospodarczych, finansów publicznych i polityki gospodarczej, rozdziałów w książkach i książek. Dorobek naukowy ogniskuje się przede wszystkim wokół:

- międzynarodowych przepływów myśli naukowo-technicznej,

- międzynarodowych przepływów kapitałowych, w tym bezpośrednich inwestycji zagranicznych i kredytów zagranicznych,

- różnych aspektów funkcjonowania małych i średnich przedsiębiorstw,

- finansów państwa, ze szczególnym uwzględnieniem polityki budżetowej.

Janina Pach, associate professor of Economic Sciences, Head of Department of Economics and Economic Policy of the Pedagogical University of Cracow. The author of numerous articles in the field of economics, international economic relations, public finance and economic policy, chapters in books and whole books. Academic achievements focus mainly on:

- -international flows of scientific and technical solution,

- -international capital flows, including foreign direct investments and foreign loans,

- -various aspects of the functioning of small and medium enterprises,

- -public finance, with special emphasis on fiscal policy.

\section{Adres/address:}

Uniwersytet Pedagogiczny w Krakowie Instytut Prawa, Administracji i Ekonomii Katedra Ekonomii i Polityki Gospodarczej ul. Podchorążych 2, 30-084 Kraków, Polska e-mail: janina.pach@poczta.onet.pl 